\title{
Effect of otolaryngology residency program on confidence of obstructive sleep apnea managements
}

Khosro Sadeghniiat-Haghighi

Tehran University of Medical Sciences

Farrokh Heidari

Tehran University of Medical Sciences

Saeed Sohrabpour

Tehran University of Medical Sciences

Arezu Najafi

Tehran University of Medical Sciences

Seyyed Amir Yasin Ahmadi

Tehran University of Medical Sciences

Reza Erfanian ( $\nabla$ r_erfanian@sina.tums.ac.ir)

Tehran University of Medical Sciences

\section{Research}

Keywords: obstructive sleep apnea, knowledge and attitude, resident physicians, otolaryngology, educational program

Posted Date: June 19th, 2020

DOI: https://doi.org/10.21203/rs.3.rs-36092/v1

License: (9) This work is licensed under a Creative Commons Attribution 4.0 International License. Read Full License 


\section{Abstract \\ Background}

According to the importance of obstructive sleep apnea syndrome managements by otolaryngologists, this study was designed to investigate knowledge, attitudes and practice of junior and senior residents of otolaryngology and evaluate the effect of current residency training program on choosing the first lines of treatment.

\section{Methods}

A total of 110 residents of otolaryngology were selected. Our study tools were obstructive sleep apnea knowledge and attitudes (OSAKA and OSAKA-KIDS) questionnaires. The participants were classified as junior and senior.

\section{Results}

Senior residents had significantly higher total knowledge score for OSAKA based on independent $t$ test (12.73 VS 10.52). No significant difference was observed for OSAKA-KIDS (11.31 VS 10.69). Also, senior residents had significantly higher total attitude score (except management with CPAP) for OSAKA. The most frequent choice for the first line treatment was CPAP (63.8\%) and weight loss (41.5\%) among junior and senior residents, respectively.

\section{Conclusions}

Although the knowledge of otolaryngology residents increased during their program, the choice of first line treatment in obstructive sleep apnea was different between junior and senior residents. We found a need for further multidisciplinary education for residents especially in the management of sleep apnea particularly toward CPAP usage and this syndrome in pediatrics.

\section{Introduction}

Sleep disorders are common problems affecting quality of daily life. One of the categories of sleep disorders is respiratory problems. Obstructive sleep apnea-hypopnea syndrome is a common disorder associated with episodes of collapse of upper airway during sleep. Knowing obstructive sleep apnea is important because it has had an increasing incidence rate during recent years ${ }^{1}$. According to different cutoff points of apnea-hypopnea index (AHI), prevalence of obstructive sleep apnea will differ. It is estimated that about $2-4 \%$ of general population have this disorder. Prevalence of obstructive sleep apnea is increased along with increasing age and obesity in the world. Obstructive sleep apnea is an independent risk factor for cardiovascular diseases, depression, and diabetes with a great burden on 
society ${ }^{2}$. It has been observed that financial burdens had been decreased following to treatment of cases in surveillance of countries ${ }^{3}$.

Prevalence of obstructive sleep apnea in children is about $1.2-5.7 \%{ }^{4}$. It has different etiology and complications in comparison to adult patients. The complications consist of growth disorders ${ }^{5}$, pulmonary hypertension and cor pulmonale, systemic hypertension ${ }^{6}$, neurocognitive and neurobehavioral complications $^{7}$.

Most patients with obstructive sleep apnea remain undiagnosed which may be due to lack of knowledge of physicians ${ }^{8}$. According to the importance of management of obstructive sleep apnea by otolaryngologists, this study was designed to investigate knowledge and attitudes of Iranian resident physicians of otolaryngology about this disease by using obstructive sleep apnea knowledge and attitudes (OSAKA) obstructive sleep apnea knowledge and attitudes in children (OSAKA-KIDS) and questionnaire with descriptive and analytical approaches. In addition, we wished to evaluate the effect from number of residency years on choosing the lines of treatment in obstructive sleep apnea.

\section{Materials And Methods}

A total of 110 resident physicians of otolaryngology were selected for this questionnaire-based crosssectional study. The participants were selected from junior and senior residents by convenient sampling from the participants of 16th International Congress of Iranian Society of Otorhinolaryngology, Head and Neck Surgery (ICIS-ORLHNS), 27-30 Nov 2018. The participants were classified as junior when they were in the first and second years and senior when they were beyond second year. A place was considered for completing the questionnaires and taking informed consent. Along with the main questionnaires another questionnaire was used for demographic information including years of residency, and their preferred first, second and third lines of treatment. Our sample size had $80 \%$ power to detect significant difference between two groups of junior and senior residents with incidence rates of $36 \%$ and $64 \%$ with 0.05 alpha errors.

Tools of study were OSAKA and OSAKA-KIDS questionnaires. OSAKA was developed by Schotland and Jeffe in $2003^{9}$, and OSAKA-KIDS was developed by Uong et al. in $2005^{10}$. Each of the above questionnaires has knowledge and attitude parts. The knowledge part of each questionnaire consists of 18 items with 3 choices of "true", "false" and "I don't know". The attitude part of these questionnaires has 5 items with 5-point Likert scale from "not important" to "extremely important" for 2 items and from "strongly disagree" to "strongly agree" for the other 3 items. The attitude part of the two questionnaires was same so our study had just one attitude part. At the end of the questionnaires, a question was added about choosing the first, second and third lines of treatment. There were 6 choices of weight loss, avoid supine position during sleep, nasal spray, surgery, CPAP and others. The questionnaires were translated to Persian language by 2 otolaryngologists who were expert in English language and validated by referring to 2 sleep medicine fellowships and 8 otolaryngology academic members who were expert in sleep apnea and English language, and they compared the translated questionnaires with their main versions. Finally, 
all the authors approved representativeness of the questionnaires. Cronbach alpha was used for reliability of the questionnaires.

Giving correct answer by at least $50 \%$ of the junior residents and $70 \%$ of the senior residents was considered as acceptable percent for each question of OSAKA and OSAKA-KIDS.

The present study was approved by the ethics committee of Tehran University of Medical Sciences. All the participants gave us informed consent. For statistical analysis Pearson chi-square, independent samples t-test and Kruskal Wallis were used according to their indications using SPSS 24 (IBM, US). Two tailed $p$ value 0.05 was considered as significance level.

\section{Results}

Among 110 resident physicians, 69 (62.8\%) residents were junior and 41 (37.2\%) residents were senior. Fifty percent of junior residents and $51.2 \%$ of senior residents were female. The mean age of junior residents was 28.7 years with standard deviation of 2.4 and the mean age of senior residents was 29 with standard deviation of 2.9 (table 1). Descriptive statistics was done for the individual questions of OSAKA (table 2) and OSAKA-KIDS (table 3). Cronbach alpha for junior and senior residents were 0.42 and 0.72 , respectively for OSAKA, and 0.38 and 0.76 , respectively for OSAKA-KIDS.

\section{Knowledge part of OSAKA and OSAKA-KIDS}

The questions with less than $50 \%$ correct answer among the juniors were "Uvulopalatopharyngoplasty is curative for majority of the patients" (40\%), "treatment with continuous positive airway pressure (CPAP) can result in nasal congestion" (25\%), "Alcohol at bedtime improves obstructive sleep apnea" (46\%), "obstructive sleep apnea is more common in women than men" (27\%), and "less than 5 apnea/hypopnea is normal in adults " $(49 \%)$ in OSAKA, and "about $10 \%$ of children snore at a regular basis" (45\%), "severity of snoring correlates with severity of obstructive sleep apnea in children" (32\%), "children younger than 2 years should have polysomnography prior to obstructive sleep apnea surgery" (45\%), and "cardiorespiratory monitor can reliably detect central and obstructive apnea in infants" (17\%) in OSAKAKIDS.

The questions with less than $70 \%$ correct answer among the seniors were "treatment with CPAP can result in nasal congestion" (34\%), "The most common cause of obstructive sleep apnea in children is the presence of large tonsil and adenoid" (53\%), "Alcohol at bedtime improves obstructive sleep apnea" (61\%), "collar size $43 \mathrm{~cm}$ or more in men is associated with obstructive sleep apnea" (58\%), "obstructive sleep apnea is more common in women than men" (56\%), and "less than 5 apnea/hypopnea is normal in adults" $(63 \%)$ in OSAKA, and "about $10 \%$ of children snore at a regular basis" (51\%), "about $2 \%$ of children have obstructive sleep apnea" (49\%), "Polysomnogram is needed to differentiate primary snoring from obstructive sleep apnea syndrome in children" (68\%), "severity of snoring correlates with severity of obstructive sleep apnea in children" (61\%), "excessive upper airway muscle tone loss during sleep contributes to obstructive sleep apnea in children" (58\%), "snoring is most frequently reported at ages 2-8 
years" (56\%), "cardiac arrhythmia may be associated with untreated obstructive sleep apnea" (66\%), "children with sickle cell disease are at increased risk of obstructive sleep apnea" (29\%), "children younger than 2 years should have polysomnography prior to obstructive sleep apnea surgery" (34\%), "significant OSA can occur without snoring in children" (63\%), and " cardiorespiratory monitor can reliably detect central and obstructive apnea in infants" (44\%) in OSAKA-KIDS.

Inferentially, significant difference was found between junior and senior residents in correct answering of the following questions based on Pearson chi-square test: For OSAKA, "uvulopharyngoplasty surgery is curable for most of the patients" ( $P<0.001$; better answer in the seniors), "overnight sleep study is the diagnostic gold standard of obstructive sleep apnea" ( $P=0.047$; better answer in the seniors), "loosing of tonicity of upper airway muscles during sleep helps formation of obstructive sleep apnea" $(P=0.004$; better answer in the seniors), "enlarged palatine tonsil and enlarge adenoid are the most prevalent reasons of obstructive sleep apnea in children" ( $P=0.032$; better answer in the seniors), "examination of pharynx, facial bones and cranial bones is useful in a patient suspected to obstructive sleep apnea", ( $P$ $=0.032$; better answer in the seniors), "lack of treatment of obstructive sleep apnea is associated with increased driving accidents" ( $P=0.008$; better answer in the seniors), and "obstructive sleep apnea is more common in women than men" ( $P=0.003$; better answer in the seniors) (table 2); for OSAKA-KIDS, "about $2 \%$ of children have obstructive sleep apnea" ( $P=0.018$; better answer in the juniors), "severity of snoring is correlated with severity of obstructive sleep apnea in children" ( $P=0.003$; better answer in the seniors), "children with sickle cell anemia have more risk of obstructive sleep apnea" $(P=0.028$; better answer in the juniors), and "cardiopulmonary monitoring can confidently detect central and obstructive apnea in infants" ( $P=0.003$; better answer in the seniors) (table 3).

\section{Attitude part of OSAKA and OSAKA-KIDS}

In the following cases, for OSAKA, attitude of the juniors and the seniors were different based on Pearson chi-square test in 2 by 5 tables: "obstructive sleep apnea from the viewpoint of a clinical disease" ( $P$ $=0.004)$, "Identifying patients with possible obstructive sleep apnea" $(P=0.002)$, "I have enough selfconfidence to find a patient who is at risk of obstructive sleep apnea" $(P=0.001)$, and "I have enough ability to be involved with patients with obstructive sleep apnea" $(P=0.003)$. No significant difference was observed for "I have enough ability to treat the patients with CPAP" $(P=0.290)$. In the following cases, for OSAKA-KIDS, attitude of the juniors and the seniors were different based on Pearson chi-square test in 2 by 5 tables: "obstructive sleep apnea from the viewpoint of a clinical disease" $(P=0.002)$, "finding the diseases resulting in obstructive sleep apnea" $(P=0.002)$, "I have enough self-confidence to find a patient who is at risk of obstructive sleep apnea" $(P=0.003)$, and "I have enough ability to be involved with patients with obstructive sleep apnea" $(P=0.002)$. No significant difference was observed for "I have enough ability to treat the patients with CPAP" $(P=0.051)$ (table 4$)$.

\section{Total score of knowledge and its association with attitude}

Total score of knowledge was compared between the juniors and the seniors. Senior residents had significantly higher total knowledge score for OSAKA based on independent $t$ test $(12.73 \pm 3.13 \mathrm{VS}$ 
$10.52 \pm 2.63 ; \mathrm{P}<0.001)$ (table 2). No significant difference was observed for OSAKA-KIDS $(11.31 \pm 3.59$ VS $10.69 \pm 2.49 ; P=0.288$ ) (table 3 ). Association of total score of knowledge with attitude status was analyzed using Kruskal Wallis test. According to this, for OSAKA, total knowledge score was associated with attitude from the viewpoint of clinical importance of sleep apnea in both junior $(P=0.025)$ and senior $(P=0.003)$ residents, total knowledge score was associated with attitude from the viewpoint of clinical importance of finding patients with obstructive sleep apnea in both junior $(P=0.006)$ and senior $(P$ $=0.034)$ residents, total knowledge score was associated with self-attitude to ability of finding patients with obstructive sleep apnea in both junior $(P<0.001)$ and senior $(P=0.001)$ residents, total knowledge score was associated with self-attitude to ability to be involved with patients with obstructive sleep apnea in junior ( $P=0.028)$ residents however not in the seniors $(P=0.052)$, and no significant association was observed for self-attitude to ability to treat the patients with CPAP in junior $(P=0.141)$ and senior $(P$ $=0.139)$ residents. For OSAKA-KIDS, total knowledge score was associated with attitude from the viewpoint of clinical importance of sleep apnea in senior $(P=0.029)$ but not in junior $(P=0.290)$ residents, total knowledge score was associated with attitude from the viewpoint of clinical importance of finding patients with obstructive sleep apnea in senior $(P=0.013)$ but not in junior $(P=0.216)$ residents, no significant association was observed for self-attitude to ability of finding patients with obstructive sleep apnea in junior $(P=0.081)$ and in senior $(P=0.392)$ residents, no significant association was observed for self-attitude to ability to be involved with patients with obstructive sleep apnea in junior $(P=0.117)$ and in senior $(P=0.478)$ residents, and no significant association was observed for self-attitude to ability to treat the patients with CPAP in junior $(P=0.495)$ and senior $(P=0.838)$ residents.

Correlation of total knowledge score in OSAKA with total knowledge score in OSAKA-KIDS was determined in junior and senior residents. According to this, positive correlation was found for both junior and senior residents $(P<0.001)$.

\section{Choosing the first lines of treatment}

Effect of being junior or senior on choosing the first lines of treatment was analyzed using Pearson chisquare. According to this, significant association was found for first $(P=0.006)$ and third lines $(P=0.014)$ however not in second line $(P=0.274)$. The most frequent choice for the first line was CPAP $(63.8 \%)$ and weight loss (41.5\%) among junior and senior residents, respectively. The most frequent choice for the third line was weight loss (29.0\%) and surgery (22.0\%) among junior and senior residents, respectively.

\section{Discussion}

Current study indicated scientific needs of junior and senior residents. According to this, the needs of junior residents were information about CPAP, knowing risk factors of obstructive sleep apnea, knowing the role of surgery and knowing parameters of polysomnography. The needs of senior residents were epidemiological information, information about CPAP, knowing risk factors of obstructive sleep apnea and knowing the results of polysomnography. The inferential results showed that senior residents had significantly better answering for 7 questions of OSAKA and 2 questions of OSAKA-KIDS. Junior residents 
had significantly better answering only for 2 questions of OSAKA-KIDS. These questions were about prevalence of obstructive sleep apnea in children and role of sickle cell anemia. The low prevalence of sickle cell anemia across Iran may be the cause this result although there are some providences in Iran which has high rate for sickle cell anemia as $1.3 \%$ of population ${ }^{11}$. This knowledge is so important of otolaryngologist surgeons as the crisis would be occurred in operation room ${ }^{12}$. This study showed that during residency training the residents would find the results which can be get from surgery and importance of preoperative results would have effect on the results of surgery. The inferential results of the attitude part in both OSAKA and OSAKA-KIDS showed that attitude was different between junior and senior residents and could affect their knowledge, except the attitude item about using CPAP. The same attitude about the CPAP therapy would be root from lack of proper education about CPAP device during otolaryngology. This result confirmed more junior residents would choose CPAP than senior residents. Choosing first and third lines of treatment was different between junior and seniors. CPAP was the first line of treatment from the viewpoint of the juniors whereas weight loss was the first line of treatment from the view point of the seniors. Total score of knowledge was not significantly different between junior and senior residents in OSAKA-KIDS. In other words, it was so important to put more emphasis on management of children sleep apnea management as the role of otolaryngologist would be more important because the role of CPAP therapy may be lower in this population. Total knowledge score in OSAKA and OSAKA-KIDS had positive correlation in both junior and senior residents.

Schotland and Jeffe (2003) developed OSAKA questionnaire based on data from 115 physicians. The mean of total knowledge score was $13.3 \pm 2.8$ out of 18 . No significant difference was found between genders. The 5 attitude items were correlated with each other. Age was negatively correlated with knowledge and 1 item of attitude which was about self-confidence to manage patients with obstructive sleep apnea. Cronbach alpha for the knowledge part was $0.76^{9}$. By compression our results with those we can conclude the Iranian physician knowledge about sleep apnea should be reinforced. Uong et al. (2005) in a study in which developed OSAKA-KIDS questionnaire considering this rationale that lack of treatment of obstructive sleep apnea results in serious complications. This questionnaire was mailed to 1195 physicians. All the items had more than $50 \%$ correct answering except the question about the role of sickle cell disease with $14.5 \%$ correct answering ${ }^{10}$. In our study, this question senior residents had significantly lower correct answering (29.3\%) compared with junior residents $(50.7 \%)$ as their medical knowledge about this disease may be decreased during residency due to recede from internal medicine education.

Ojeda et al. (2013) performed a study on Latin American primary care physicians using Spanish version of OSAKA. A number of 367 physician responded the questionnaire with total knowledge score $60 \%$. The least correct answering was for the question about association of cardiac arrhythmia with untreated obstructive sleep apnea (18.5\%) ${ }^{13}$. In another report of this work, Ojeda et al. (2018) compared recent graduates with practicing physicians. Practicing physicians showed better total knowledge score ${ }^{14}$. Ozoh et al. (2015) in Nigeria, performed a study on 143 graduating medical students using OSAKA. Total knowledge and total attitude score showed a significant positive correlation. In the attitude part, over $80 \%$ 
of the participants considered obstructive sleep apnea as an important disorder ${ }^{15}$. Williams et al. (2015) investigated referral rate of physicians and its association with knowledge and attitude. Total referral rate was $75 \%$; however, it was not influenced by knowledge and attitude of physicians. Patients inquiring about obstructive sleep apnea significantly increased referral rate with adjusted odds ratio $9.38^{16}$. Li et al. (2016) in China, studied 560 physicians using OSAKA and their viewpoints on treatment lines. Total knowledge score was $44.87 \%$. The participants ranked treatment lines as weight loss, quit smoking and alcohol, CPAP, avoid fatigue, surgery and drugs. The mentioned lines were different from the lines of our study ${ }^{17}$. Corso et al. (2017) in Italy, studied knowledge and attitude of 370 anesthetists using OSAKA. Total knowledge score was 11.8 in which anesthetists with more than 15 years of experience showed better score compared with anesthesiology residents ${ }^{18}$. Goyal et al. (2018) in India, studied 232 final-year medical students using OSAKA and OSAKA-KIDS. Total knowledge score was $37.9 \%$ and $42.1 \%$ for OSAKA and OSAKA-KIDS, respectively. They found that there was not enough knowledge in spite of enough attitude and thinking about the importance of the disorder ${ }^{19}$. Jokubauskas et al. (2018) in a nation-wide study in Lithuania, studied knowledge and attitude of 353 dentists using OSAKA. Increased years of experience was significantly associated with less knowledge. There was no significant difference between general dentists and specialists ${ }^{20}$. Canadian residents of otolaryngology were evaluated by OSAKA in 2020. The total score of knowledge was $88.9 \%$ and in the attitude part they had greatest problem with CPAP and just $15.2 \%$ were confident with in managing CPAP. The senior residents had better knowledge scores and had better confident towards identifying patients at risk for obstructive sleep apnea, ability to manage these patients and even management of patient with CPAP ${ }^{21}$.

Knowledge and insights of physicians about common medical conditions is very important to increase level of public health ${ }^{22}$. Educations should be presented for medical students as well as graduated physicians including residents and specialists. It has been shown that education of the targeted population results in better public health and reduction of burdens ${ }^{23,24}$. The case obstructive sleep apnea is not an exception and the positive results of education has been investigated ${ }^{25}$. This is first study which analyzed the otolaryngology education program on knowledge and attitude toward obstructive sleep apnea.

From the limitations of our study, selection bias of the participants in the congress can be pointed out. Voluntary participation helped us to achieve more reliable and patiently answering, however might be resulted in participation of the residents with more interest in research and in the topic. Regarding previous literature, we had some strengths such as simultaneous investigation of OSAKA and OSAKAKIDS and choosing treatment lines from the view point of otolaryngology residents. Otolaryngology specialists, fellowships, fellows and residents are very important targeted group in this topic.

\section{Conclusion}

Knowledge and attitudes about obstructive sleep apnea were different between junior and senior residents. Therefore, resident physicians of otolaryngology need further education. According to the 
literature knowledge of different specialties were different; in some specialties higher practical experience was associated with better knowledge and in some other groups it was vice versa. Quasi experimental studies are suggested to investigate the outcomes of education on patient management and prevention adverse effect of obstructive sleep apnea.

Practice implications: Otolaryngologists should be aware of obstructive sleep apnea to manage such patients. Therefore, they should be educated and educate the patient.

\section{Abbreviations}

Apnea-hypopnea index (AHI), obstructive sleep apnea knowledge and attitudes (OSAKA), obstructive sleep apnea knowledge and attitudes in children (OSAKA-KIDS), continuous positive airway pressure (CPAP), obstructive sleep apnea (OSA)

\section{Declarations}

\section{Acknowledgements}

We thank the holders of international congress of Iranian society of otolaryngology, head and neck surgery, 27-30 Nov 2018.

\section{Conflicts of interest}

The authors declare no conflict interest. The project was performed voluntary.

\section{Financial disclosures}

None

\section{Availability of data and materials}

Not applicable

\section{Consent for publication}

Not applicable

\section{Ethics approval and consent to participate}

The present study was approved by the ethics committee of Tehran University of Medical Sciences. All the participants gave us informed consent.

\section{Authors' contributions}


$\mathrm{KSH}, \mathrm{AN}$ and SAYA, evaluated, provided and helped for completing the questionnaires. FH and SS wrote the original draft. RE did the final editing and was responsible for the resources. All authors read and approved the final manuscript.

\section{References}

1. Gamaldo AA, Beydoun MA, Beydoun HA, et al. Sleep Disturbances among Older Adults in the United States, 2002-2012: Nationwide Inpatient Rates, Predictors, and Outcomes. Front Aging Neurosci 2016;8:266.

https://doi.org/10.3389/fnagi.2016.00266

2. Peppard PE, Young T, Palta M, et al. Prospective study of the association between sleep-disordered breathing and hypertension. N Engl J Med 2000;342:1378-84.

https://doi.org/10.1056/NEJM200005113421901

3. Bahammam A, Delaive K, Ronald J, et al. Health care utilization in males with obstructive sleep apnea syndrome two years after diagnosis and treatment. Sleep 1999;22:740-7.

https://doi.org/10.1093/sleep/22.6.740

4. Gipson K, Lu M, Kinane TB. Sleep-Disordered Breathing in Children. Pediatr Rev 2019;40:3-13.

https://doi.org/10.1542/pir.2018-0142

5. Zhang XM, Shi J, Meng GZ, et al. The effect of obstructive sleep apnea syndrome on growth and development in nonobese children: a parallel study of twins. J Pediatr 2015;166:646-50 e1.

https://doi.org/10.1016/j.jpeds.2014.11.060

6. Kaditis AG, Alonso Alvarez ML, Boudewyns A, et al. Obstructive sleep disordered breathing in 2- to 18year-old children: diagnosis and management. Eur Respir J 2016;47:69-94.

https://doi.org/10.1183/13993003.00385-2015

7. Capdevila OS, Kheirandish-Gozal L, Dayyat E, et al. Pediatric obstructive sleep apnea: complications, management, and long-term outcomes. Proc Am Thorac Soc 2008;5:274-82.

https://doi.org/10.1513/pats.200708-138MG

8. Kramer NR, Cook TE, Carlisle CC, et al. The role of the primary care physician in recognizing obstructive sleep apnea. Arch Intern Med 1999;159:965-8.

https://doi.org/10.1001/archinte.159.9.965 
9. Schotland HM, Jeffe DB. Development of the obstructive sleep apnea knowledge and attitudes (OSAKA) questionnaire. Sleep Med 2003;4:443-50.

https://doi.org/10.1016/s1389-9457(03)00073-x

10. 87Ung EC, Jeffe DB, Gozal D, et al. Development of a measure of knowledge and attitudes about obstructive sleep apnea in children (OSAKA-KIDS). Arch Pediatr Adolesc Med 2005;159:181-6.

https://doi.org/10.1001/archpedi.159.2.181

11. Ahmadzadeh A, Moghtaderi M, Zandian K. Neonatal Screening for Sickle Cell Disease in South West Iran: a Pilot Study. 2011;2.

12. Halvorson DJ, McKie V, McKie K, et al. Sickle cell disease and tonsillectomy. Preoperative management and postoperative complications. Arch Otolaryngol Head Neck Surg 1997;123:689-92.

https://doi.org/10.1001/archotol.1997.01900070033005

13. Cherrez Ojeda I, Jeffe DB, Guerrero T, et al. Attitudes and knowledge about obstructive sleep apnea among Latin American primary care physicians. Sleep Med 2013;14:973-7.

https://doi.org/10.1016/j.sleep.2013.06.005

14. Cherrez-Ojeda I, Calderon JC, Fernandez Garcia A, et al. Obstructive sleep apnea knowledge and attitudes among recent medical graduates training in Ecuador. Multidiscip Respir Med 2018;13:5.

https://doi.org/10.1186/s40248-018-0117-8

15. Ozoh OB, Iwuala SO, Desalu OO, et al. An Assessment of the Knowledge and Attitudes of Graduating Medical Students in Lagos, Nigeria, Regarding Obstructive Sleep Apnea. Ann Am Thorac Soc 2015;12:1358-63.

https://doi.org/10.1513/AnnalsATS.201412-5610C

16. Williams NJ, Nunes JV, Zizi F, et al. Factors associated with referrals for obstructive sleep apnea evaluation among community physicians. J Clin Sleep Med 2015;11:23-6.

https://doi.org/10.5664/jcsm.4356

17. Li H, Wang J, Ouyang B, et al. Attitude and knowledge of Chinese physicians towards obstructive sleep apnea syndrome. 2016;9:3433-40.

18. Corso RM, Sorbello M, Buccioli M, et al. Survey of Knowledge and Attitudes about Obstructive Sleep Apnoea Among Italian Anaesthetists. Turk J Anaesthesiol Reanim 2017;45:146-52.

https://doi.org/10.5152/TJAR.2017.51423

Page 11/19 
19. Goyal A, Aswin P, Pakhare A. Poor Knowledge and Attitude Regarding Obstructive Sleep Apnea (OSA) Among Medical Students in India: A Call for MBBS Curriculum Change. Sleep and Vigilance 2017.

https://doi.org/10.1007/s41782-017-0028-3

20. Jokubauskas L, Pileičikienè G, Zekonis G, et al. Lithuanian dentists' knowledge, attitudes, and clinical practices regarding obstructive sleep apnea: A nationwide cross-sectional study. Cranio: the journal of craniomandibular practice 2018;37:1-8.

https://doi.org/10.1080/08869634.2018.1437006

21. Ansari S, Hu A. Knowledge and confidence in managing obstructive sleep apnea patients in Canadian otolaryngology - head and neck surgery residents: a cross sectional survey. J Otolaryngol Head Neck Surg 2020;49:21.

https://doi.org/10.1186/s40463-020-00417-6

22. Lapaige V. "Integrated knowledge translation" for globally oriented public health practitioners and scientists: Framing together a sustainable transfrontier knowledge translation vision. J Multidiscip Healthc 2010;3:33-47.

https://doi.org/10.2147/jmdh.s5338

23. Davis $D A$, Thomson MA, Oxman AD, et al. Changing physician performance. A systematic review of the effect of continuing medical education strategies. JAMA 1995;274:700-5.

https://doi.org/10.1001/jama.274.9.700

24. Abdel Shaheed C, Graves J, Maher C. The effects of a brief educational intervention on medical students' knowledge, attitudes and beliefs towards low back pain. Scand J Pain 2017;16:101-4.

https://doi.org/10.1016/j.sjpain.2017.04.002

25. Valerio TD, Heaton K. The effects of an online educational program on nurse practitioners' knowledge of obstructive sleep apnea in adults. J Am Assoc Nurse Pract 2014;26:603-11.

https://doi.org/10.1002/2327-6924.12097

\section{Tables}

Table 1: demographic data for 110 participant residents 


\begin{tabular}{|c|c|c|c|}
\hline \multicolumn{2}{|c|}{} & Junior residents & Senior residents \\
\hline \multicolumn{2}{|c|}{ Numbers (percentage) } & $69(63 \%)$ & $41(37 \%)$ \\
\hline \multirow{2}{*}{$\begin{array}{c}\text { Gender } \\
\text { (numbers) }\end{array}$} & Male & 34 & 20 \\
\cline { 2 - 4 } & Female & 35 & 21 \\
\hline \multicolumn{2}{|c|}{ Age $^{*}$ (standard deviation) } & $28.7(2.4)$ & $29(2.9)$ \\
\hline
\end{tabular}

* year

Table 2: Data from the knowledge part of OSAKA questionnaire. 


\begin{tabular}{|c|c|c|c|}
\hline \multirow[t]{2}{*}{ lestion (answer) } & \multicolumn{2}{|c|}{ Correct answering in } & \multirow[t]{2}{*}{$\mathrm{P}$ value } \\
\hline & $\begin{array}{l}\text { Juniors } \\
\text { Frequency } \\
(\%)\end{array}$ & $\begin{array}{l}\text { Seniors } \\
\text { Frequency } \\
(\%)\end{array}$ & \\
\hline smen with OSA may present with fatigue alone $(\mathrm{T})$ & $60(87.0)$ & $33(80.5)$ & 0.364 \\
\hline $\begin{array}{l}\text { ulopalatopharyngoplasty is curative for majority } \\
\text { patients with OSA (F) }\end{array}$ & $28(40.6)$ & $31(75.6)$ & $<0.001 *$ \\
\hline $\begin{array}{l}\text { e estimated prevalence of OSA among adults is } \\
\text { tween } 2 \% \text { and } 10 \%(\mathrm{~T})\end{array}$ & $39(56.5)$ & $20(48.8)$ & 0.431 \\
\hline e majority of patients with OSA snore $(\mathrm{T})$ & $47(68.1)$ & $29(70.7)$ & 0.774 \\
\hline ;A is associated with hypertension ( $\mathrm{T}$ ) & $56(81.2)$ & $33(80.5)$ & 0.931 \\
\hline $\begin{array}{l}\text { ernight sleep study is the gold standard for } \\
\text { ignosing OSA (T) }\end{array}$ & $54(78.3)$ & $38(92.7)$ & $0.048^{*}$ \\
\hline $\begin{array}{l}\text { eatment with CPAP can result in nasal congestion } \\
\text {, }\end{array}$ & $17(24.6)$ & $14(34.1)$ & 0.284 \\
\hline $\begin{array}{l}\text { ser-assisted uvuloplasty is an appropriate } \\
\text { :atment for severe OSA (F) }\end{array}$ & $36(52.2)$ & $22(53.7)$ & 0.880 \\
\hline $\begin{array}{l}\text { ss of upper airway muscle tone during sleep } \\
\text { ntributes to OSA }(\mathrm{T})\end{array}$ & $45(65.2)$ & $37(90.2)$ & $0.004 *$ \\
\hline $\begin{array}{l}\text { e most common cause of OSA in children is the } \\
\text { esence of large tonsil and adenoid }(\mathrm{T})\end{array}$ & $40(58.0)$ & $32(78.0)$ & $0.032 *$ \\
\hline $\begin{array}{l}\text { aniofacial and oropharyngeal examination are } \\
\text { eful in a patient with suspected OSA (T) }\end{array}$ & $44(63.8)$ & $34(82.9)$ & $0.032 *$ \\
\hline zohol at bedtime improves OSA (F) & $32(46.4)$ & $25(61.0)$ & 0.138 \\
\hline
\end{tabular}




\begin{tabular}{|c|c|c|c|}
\hline $\begin{array}{l}\text { treated OSA is associated with higher incidence of } \\
\text { tomobile crashes }(\mathrm{T})\end{array}$ & $47(68.1)$ & $37(90.2)$ & $0.008 *$ \\
\hline $\begin{array}{l}\text { man a collar size } 43 \mathrm{~cm} \text { or greater is associated } \\
\text { th OSA }(\mathrm{T})\end{array}$ & $35(50.7)$ & $24(58.5)$ & 0.427 \\
\hline iA is more common in women than men $(\mathrm{F})$ & $19(27.5)$ & $23(56.1)$ & $0.003 *$ \\
\hline 'AP is the first therapy for severe OSA (T) & $49(71.0)$ & $33(80.5)$ & 0.270 \\
\hline $\begin{array}{l}\text { ss than } 5 \text { apnea/hypopnea per hour is normal in } \\
\text { ults (T) }\end{array}$ & $34(49.3)$ & $26(63.4)$ & 0.150 \\
\hline rdiac arrhythmia may be associated with OSA (T) & $44(63.8)$ & $31(75.6)$ & 0.197 \\
\hline $\mathrm{m}$ & $69(100)$ & $40(100)$ & \\
\hline tal score (out of 18) & 10.52 & 12.73 & $<0.001 * *$ \\
\hline
\end{tabular}

OSA: obstructive sleep apnea; T: true; F: false. * Significant at $\mathrm{P}<0.05$ according to Pearson chi-square. ${ }^{* *}$ Significant at $\mathrm{P}<0.05$ according to independent t test.

Table3: Data from the knowledge part of OSAKA-KIDS questionnaire. 


\begin{tabular}{|c|c|c|c|}
\hline \multirow[t]{2}{*}{ (answer) } & \multicolumn{2}{|c|}{ Correct answering in } & \multirow{2}{*}{ P } \\
\hline & $\begin{array}{l}\text { Juniors } \\
\text { Frequency } \\
(\%)\end{array}$ & $\begin{array}{l}\text { Seniors } \\
\text { Frequency } \\
(\%)\end{array}$ & \\
\hline with OSA may present with hyper activity $(T)$ & $50(72.5)$ & $29(70.7)$ & 0.845 \\
\hline $\mathrm{J} \%$ of children snore on a regular basis $(\mathrm{T})$ & $31(44.9)$ & $21(51.2)$ & 0.523 \\
\hline$\%$ of children have OSA $(\mathrm{T})$ & $43(62.3)$ & $16(39.0)$ & $0.018 *$ \\
\hline :hildren may be associated with pulmonary hypertension $(T)$ & $45(65.2)$ & $32(78.0)$ & 0.156 \\
\hline $\begin{array}{l}\text { Inogram is needed to differentiate primary snoring from } \\
\text { Idrome in children }(T)\end{array}$ & $46(66.7)$ & $28(68.3)$ & 0.860 \\
\hline of snoring correlates with severity of OSA in children $(\mathrm{F})$ & $22(31.9)$ & $25(61.0)$ & $0.003^{*}$ \\
\hline $\begin{array}{l}\text { 'e upper airway muscle tone loss during sleep contributes to } \\
\text { :hildren (T) }\end{array}$ & $46(66.7)$ & $24(58.5)$ & 0.391 \\
\hline $\begin{array}{l}\text { I tonsils and adenoids are the most frequent contributing } \\
\text { o OSA }(\mathrm{T})\end{array}$ & $50(72.5)$ & $36(87.8)$ & 0.060 \\
\hline $\begin{array}{l}\text { with suspected OSA should have a thorough head and neck } \\
\text { sharyngeal examination }(T)\end{array}$ & $57(82.6)$ & $33(80.5)$ & 0.780 \\
\hline with untreated OSA may be affected by learning disorders & $49(71.0)$ & $35(85.4)$ & 0.087 \\
\hline is most frequently reported at ages $2-8$ years $(T)$ & $45(65.2)$ & $23(56.1)$ & 0.341 \\
\hline arrhythmia may be associated with untreated OSA ( $T$ ) & $42(60.9)$ & $27(65.9)$ & 0.601 \\
\hline with sickle cell disease are at increased risk for OSA $(T)$ & $35(50.7)$ & $12(29.3)$ & $0.028 *$ \\
\hline $\begin{array}{l}\text { younger than } 2 \text { years should have polysomnogram prior to } \\
\text { intervention for presumed OSA }(\mathrm{T})\end{array}$ & $31(44.9)$ & $14(34.1)$ & 0.266 \\
\hline int OSA can occur without snoring in children $(T)$ & $45(65.2)$ & $26(63.4)$ & 0.848 \\
\hline o thrive is a frequent complication of OSA $(T)$ & $46(66.7)$ & $33(80.5)$ & 0.119 \\
\hline $\begin{array}{l}\text { with severe OSA may have transient worsening of } \\
\text { ry symptoms after adenotonsilectomy }(T)\end{array}$ & $43(62.3)$ & $32(78.0)$ & 0.087 \\
\hline spiratory monitor can reliably detect & $12(17.4)$ & $18(43.9)$ & $0.003^{*}$ \\
\hline
\end{tabular}




\begin{tabular}{l|l|l|l|} 
ive apnea in infants $(F)$ & & & \\
\hline & $69(100)$ & $40(100)$ & \\
\hline vre (out of 18) & 10.69 & 11.31 & $0.288 \#$ \\
\hline
\end{tabular}

OSA: obstructive sleep apnea; T: true; F: false. * Significant at P $<0.05$ according to Pearson chi-square. \# Non-significant according to independent $t$ test.

Table 4: Descriptive data from the attitude part of OSAKA questionnaire. 


\begin{tabular}{|c|c|c|c|c|}
\hline \multirow[t]{2}{*}{ Question } & \multirow{2}{*}{$\begin{array}{l}\text { Attitude } \\
\text { category }\end{array}$} & \multicolumn{2}{|l|}{ Residents } & \multirow{2}{*}{$\begin{array}{l}P \\
\text { value }\end{array}$} \\
\hline & & $\begin{array}{l}\text { Juniors } \\
\text { Frequency } \\
(\%)\end{array}$ & $\begin{array}{l}\text { Seniors } \\
\text { Frequency } \\
(\%)\end{array}$ & \\
\hline \multirow{6}{*}{$\begin{array}{l}\text { Obstructive sleep apnea from the viewpoint of a } \\
\text { clinical disease }\end{array}$} & Not important & $0(0.0)$ & $1(2.4)$ & \multirow[t]{6}{*}{$0.004^{*}$} \\
\hline & $\begin{array}{l}\text { Somewhat } \\
\text { important }\end{array}$ & $2(2.9)$ & $1(2.4)$ & \\
\hline & Important & $44(63.8)$ & $12(29.3)$ & \\
\hline & Very important & $17(24.6)$ & $14(34.1)$ & \\
\hline & $\begin{array}{l}\text { Extremely } \\
\text { important }\end{array}$ & $6(8.7)$ & $12(29.3)$ & \\
\hline & Sum & $69(100)$ & $40(100)$ & \\
\hline \multirow{6}{*}{$\begin{array}{l}\text { Identifying patients with possible obstructive sleep } \\
\text { apnea }\end{array}$} & Not important & $0(0.0)$ & $1(2.4)$ & \multirow[t]{6}{*}{$0.002 *$} \\
\hline & $\begin{array}{l}\text { Somewhat } \\
\text { important }\end{array}$ & $4(5.8)$ & $1(2.4)$ & \\
\hline & Important & $50(72.5)$ & $15(36.6)$ & \\
\hline & Very important & $11(15.9)$ & $14(34.1)$ & \\
\hline & $\begin{array}{l}\text { Extremely } \\
\text { important }\end{array}$ & $4(5.8)$ & $9(22.0)$ & \\
\hline & Sum & $69(100)$ & $40(100)$ & \\
\hline \multirow[t]{6}{*}{$\begin{array}{l}\text { I have enough self-confidence to find a patient } \\
\text { who is at risk of obstructive sleep apnea }\end{array}$} & $\begin{array}{l}\text { Strongly } \\
\text { disagree }\end{array}$ & $7(10.1)$ & $3(7.3)$ & \multirow[t]{6}{*}{$0.001 *$} \\
\hline & Disagree & $41(59.4)$ & $9(22.0)$ & \\
\hline & $\begin{array}{l}\text { Neither agree } \\
\text { nor disagree }\end{array}$ & $7(10.1)$ & $6(14.6)$ & \\
\hline & Agree & $12(17.4)$ & $16(39.0)$ & \\
\hline & Strongly agree & $2(2.9)$ & $6(14.6)$ & \\
\hline & Sum & $69(100)$ & $40(100)$ & \\
\hline I have enough ability to be involved with patients & Strongly & $6(8.7)$ & $2(4.9)$ & $0.003^{*}$ \\
\hline
\end{tabular}




\begin{tabular}{|c|c|c|c|c|}
\hline \multirow[t]{6}{*}{ with obstructive sleep apnea } & disagree & & & \\
\hline & Disagree & $40(58.0)$ & $11(26.8)$ & \\
\hline & $\begin{array}{l}\text { Neither agree } \\
\text { nor disagree }\end{array}$ & $13(18.8)$ & $9(22.0)$ & \\
\hline & Agree & $8(11.6)$ & $11(26.8)$ & \\
\hline & $\begin{array}{l}\text { Strongly } \\
\text { agree }\end{array}$ & $2(2.9)$ & $7(17.1)$ & \\
\hline & Sum & $69(100)$ & $40(100)$ & \\
\hline \multirow[t]{6}{*}{$\begin{array}{l}\text { I have enough ability to treat the patients with } \\
\text { CPAP }\end{array}$} & $\begin{array}{l}\text { Strongly } \\
\text { disagree }\end{array}$ & $12(17.4)$ & $6(14.6)$ & \multirow[t]{6}{*}{0.290} \\
\hline & Disagree & $28(40.6)$ & $15(36.6)$ & \\
\hline & $\begin{array}{l}\text { Neither agree } \\
\text { nor disagree }\end{array}$ & $23(33.3)$ & $10(24.4)$ & \\
\hline & Agree & $6(8.7)$ & $8(19.5)$ & \\
\hline & Strongly agree & $0(0.0)$ & $1(2.4)$ & \\
\hline & Sum & $69(100)$ & $40(100)$ & \\
\hline
\end{tabular}

* Significant difference in junior and senior residents at $\mathrm{P}<0.05$ according to Pearson chi-square in 2 by 5 tables. 